Please do not remove this page

RMIT

UNIVERSITY

\title{
Typology of new psychoactive substance use among the general Australian population
}

Sutherland, Rachel; Peacock, Amy; Roxburgh, Amanda; Barratt, Monica; Burns, Lucinda; Bruno, Raimondo https://researchrepository.rmit.edu.au/esploro/outputs/9921860919001341/filesAndLinks?institution=61 RMIT_INST\&index=null

Sutherland, R., Peacock, A., Roxburgh, A., Barratt, M., Burns, L., \& Bruno, R. (2018). Typology of new psychoactive substance use among the general Australian population. Drug and Alcohol Dependence, 188, 126-134. https://doi.org/10.1016/j.drugalcdep.2018.03.034

Document Version: Accepted Manuscript

Published Version: https://doi.org/10.1016/j.drugalcdep.2018.03.034

Repository homepage: https://researchrepository.rmit.edu.au

CC BY-NC-ND V4.0

(C) 2018 Elsevier B.V. All rights reserved.

Downloaded On 2023/04/26 12:59:17 +1000 
This document is the non-formatted post-review paper that was published at:

https://doi.org/10.1016/j.drugalcdep.2018.03.034

\section{Typology of new psychoactive substance use among the general Australian population 'Running title': Typology of new psychoactive substance use}

Rachel Sutherland ${ }^{* 1}$, Amy Peacock $^{1,2}$, Amanda Roxburgh $^{1}$, Monica J. Barratt ${ }^{1,3,4}$, Lucinda

$$
\text { Burns }{ }^{1} \text {, Raimondo Bruno }{ }^{2}
$$

${ }^{1}$ National Drug and Alcohol Research Centre, University of New South Wales, Sydney, NSW, 2052,

Australia

${ }^{2}$ School of Medicine (Psychology), Faculty of Health, University of Tasmania, Hobart, TAS, 7001,

Australia

${ }^{3}$ National Drug Research Institute, Faculty of Health Sciences, Curtin University, Perth, WA, 6845,

Australia

${ }^{4}$ Behaviours and Health Risks Program, Burnet Institute, 85 Commercial Rd, Melbourne VIC 3004,

Australia

Journal: Drug and Alcohol Dependence

Number of tables: 4

Number of figures: 2

Corresponding Author*: Rachel Sutherland

National Drug and Alcohol Research Centre, University of New South Wales, Sydney, NSW, 2052,

AUSTRALIA; Phone: +61 29385 0256; Facsimile: +61 (0)2 9385 0222; E-mail: $\underline{\text { rachels@unsw.edu.au }}$

Conflict of interest declaration: None. 


\section{ABSTRACT}

Aim: The aim of this study was to examine the typology of Australian illicit drug consumers to determine whether those who use new psychoactive substances (NPS) differ from those using other illicit substances.

Methods: Data were from the 2013 National Drug Strategy Household Survey, a representative population study; analyses were limited to participants reporting past year illicit drug use (including NPS; $n=3,309)$. Latent class analysis identified groups based on past year substance use, and a weighted multivariable, multinomial regression model was used to examine characteristics associated with group membership.

Results: Six consumer typologies were identified: cannabis consumers (46\%), pharmaceutical consumers (21\%), ecstasy and cocaine consumers (19\%), amphetamine and cannabis consumers (7\%), polysubstance consumers (6\%), and inhalant consumers (2\%). Sixteen participants (total sample: 0.07\%; NPS consumers: 5.7\%) reported exclusive NPS use. Synthetic cannabinoid receptor agonist use was highest among amphetamine and cannabis consumers and polysubstance consumers; other NPS use was highest among polysubstance consumers. Polysubstance consumers were younger than all other groups, and more likely to engage in dangerous activities while under the influence of substances, inject drugs and report hazardous alcohol consumption. Amphetamine and cannabis consumers were more likely to report trouble ceasing their drug use.

Conclusion: We found no distinct profile of NPS-only consumers; however, NPS use was a marker for more problematic patterns of use. Our findings suggest that specialised NPS interventions or harm reduction messages may not be required in the Australian context; rather, they could be based upon existing responses to drug use.

Keywords: New psychoactive substances; NPS; synthetic cannabinoids; typology; latent class analysis 


\section{Introduction}

Over the past decade, the number and range of substances collectively referred to as 'new psychoactive substances' (NPS) has increased dramatically. NPS are defined by the European Monitoring Centre for Drugs and Drug Addiction (EMCDDA) as substances which do not fall under international drug controls but which may pose a public health threat (European Monitoring Centre for Drugs and Drug Addiction, 2016b). However, there are a number of problems with this definition (e.g. mere psychoactivity is assumed to be a public health threat; Barratt et al., 2017), and in practicality the term 'NPS' has come to include drugs which have previously not been well-established in recreational drug markets, or which are not well documented. In 2016 over 600 NPS were being monitored by the European Union (European Monitoring Centre for Drugs and Drug Addiction, 2016a), of which $70 \%$ were detected in the past five years (European Monitoring Centre for Drugs and Drug Addiction, 2016b).

Despite the rapid growth of the NPS market, and associated concerns of widespread use, prevalence appears to be relatively low amongst adult general population samples (i.e. $\leqslant 1.2 \%$; Home Office, 2017, Australian Institute of Health \& Welfare, 2017, Palamar et al., 2015). The use of these substances is thought to be concentrated amongst existing illicit drug consumers (Moore et al., 2013, Sutherland et al., 2016), and other disadvantaged groups (e.g. homeless, prisoners, mentally ill, people who inject drugs; European Monitoring Centre for Drugs and Drug Addiction, 2017b, Joseph et al., 2017, Manseau et al., 2017, Rácz et al., 2016, Tarján et al., 2017). Concerns remain, however, that 'novice' consumers may initiate NPS use, particularly given use of the internet as a means of supply. Indeed, the argument that NPS appeal to novice consumers has been used to advocate for their prohibition, regardless of their harm profile, on the premise of preventing normalisation of NPS use and transition into other illicit drug use (Intergovernmental Committee on Drugs, 2014). 
Our ability to address such concerns is limited by the fact that the comparability of NPS consumers with other illicit drug consumers has not been properly explored. Subsequently, it remains unclear whether there is a distinct group of exclusive NPS consumers (i.e. people who use NPS but no other illicit substances), or whether there are particular groups of illicit drug consumers that report elevated rates of NPS use. In order to examine these questions, data from samples where inclusion is not based on illicit substance use, and where people may be consuming a broad range of substances, are required. General population data provide an important opportunity to answer this research question, with latent class analysis (LCA) a particularly suitable method for investigating whether distinct subtypes or classes of NPS consumers exist.

In identifying NPS consumers, it is critical to explore their relative demographic and risk profile. Previous studies have shown that people who report NPS use are typically younger, more likely to be male, report higher levels of poly drug use, younger age of drug initiation, more problematic drug use (e.g. bingeing), and are more likely to report online purchasing behaviours relative to illicit drug consumers who do not use NPS (Bonar et al., 2014, Bruno et al., 2012, Lawn et al., 2014, Palamar, 2015, Palamar and Acosta, 2015, Emmanuel and Attarad, 2006). However, these studies are generally based on samples of people who use illicit drugs, limiting their capacity to identify unique NPS groups (including people using NPS but no other illicit substances).

As such, this study uses data from a general population sample to:

1) Examine the typology of Australian illicit drug consumers to determine if there is a distinct group of exclusive NPS consumers, and if not, determine which consumer 'type' is most likely to use NPS.

2) Compare profiles across these subgroups, based on demographics and risk behaviours. 
This information will improve our understanding of the profiles of NPS users, allowing for the development of more targeted harm reduction messages.

\section{Method}

\subsection{Study design and participants}

This paper uses data from the 2013 National Drug Strategy Household Survey (NDSHS; for full protocol details, see Australian Institute of Health \& Welfare, 2014). The NDSHS, conducted on a triennial basis, collects data from the Australian residential population, and employs a multistage stratified sampling methodology designed to provide a close-to-random sample to obtain data on drug and alcohol use in the Australian population over 14 years of age. In $2013,23,855$ respondents participated in the survey, with analyses based on a subset of participants who reported past year use of a range of licit drugs used for non-medical purposes (e.g. opioid analgesics) and/or illicit drugs, including NPS $(n=3,309 ; 13.9 \%)$.

\subsection{Measures relevant to the current study}

\subsubsection{Licit and illicit drug use}

Participants were asked about their lifetime and past twelve-month use of a range of licit and illicit substances, including tobacco, alcohol, pharmaceutical drugs used for non-medical purposes (i.e. pain killers/analgesics, tranquilisers/sleeping pills, steroids, methadone or buprenorphine, other opiates/opioids), methamphetamine, cannabis, heroin, cocaine, hallucinogens, ecstasy, ketamine, GHB and inhalants. The 2013 NDSHS was the first in the survey series to include questions about NPS. Specifically, participants were asked about their lifetime and past 12 month use of "synthetic cannabis/cannabinoids (e.g. K2, Spice, Kronic)" and "novel psychoactive substances (e.g. mephedrone, methylone, BZP, 2C-B, DMT, MDAI, MDPV)". Hence, for the purposes of this paper NPS will be split 
into two categories: synthetic cannabinoids (hereafter referred to as synthetic cannabinoid receptor agonists; SCRA) and other NPS.

\subsubsection{Demographics and mental health}

The 2013 NDSHS survey collected a range of demographic information, including age, gender, income (AUD), employment and educational status. Relative socio-economic advantage and disadvantage was measured using the Socio-Economic Indexes for Areas (SEIFA), developed by the Australian Bureau of Statistics (Australian Bureau of Statistics, 2013). From this index, areas can be divided into quintiles, with the lowest quintile representing the most disadvantaged areas and the highest quintile representing the most advantaged. This SEIFA quintile variable was included in analyses as an arealevel indicator of socio-economic status (SES), with the bottom two quintiles combined to signify the most disadvantaged quintiles.

Participants were also administered the Kessler 10 (K10) Psychological Distress Scale to assess psychological distress (Kessler et al., 2003). The K10 is a 10-item screening tool utilizing a five-point response scale ( 1 'none of the time' to 5 'all of the time'); a cut-off score of $\geq 22$ (score range 10-50) was used to measure high to very high psychological distress (Andrews and Slade, 2001).

\subsubsection{Alcohol and drug-related risk behaviours}

The 2013 NDSHS asked participants how many days of work, school, TAFE or university they had missed because of their alcohol use, and how many days they had missed because of their use of drugs other than alcohol, in the past three months. Responses to this variable were recoded into a binary variable with yes/no response options (i.e. did the participant miss any days of work, school, TAFE or university because of their alcohol and/or drug use).

They were also asked if, in the last 12 months, they had done any of the following activities while under the influence of or affected by alcohol or illicit drugs: went to work; went swimming; operated 
a boat; drove a motor vehicle; operated hazardous machinery; created a public disturbance or nuisance; cause damage to property; stole money, goods or property; verbally abused someone; or physically abused someone.

Participants who had used non-medicinal pain killers/analgesics, tranquilisers/sleeping pills, methamphetamine, cannabis, heroin, tobacco, steroids, buprenorphine, cocaine, hallucinogens, ecstasy or inhalants were asked if, in the past 12 months, they could not stop or cut down on their use of these substances even though they wanted to or tried to. Participants who had not used these substances were coded as 'no'.

The Alcohol Use Disorders Identification Test Consumption questions (AUDIT-C) was administered as a validated screening measure of hazardous patterns of alcohol consumption (Bradley et al., 2007, Bush et al., 1998). This 3-item scale assesses quantity and frequency of use, with higher scores (range 0-12) indicating more hazardous use. Participants were categorised based on a cut-off indicative of high risk drinking (scores of 9 and above; Harris et al., 2010). Participants who had not consumed alcohol in the past year were given a score of ' 0 '.

Participants were also asked if they had injected any drugs (where injection was the non-intended route of administration for pharmaceutical medicines) in the last 12 months.

\subsection{Statistical analysis}

To address the first aim, latent class models (one to eight classes) were estimated using past year drug and alcohol use. Specifically, the models were based on past 12 month use of the following drugs: cannabis, ecstasy, meth/amphetamine, cocaine, hallucinogens, inhalants, SCRA, other NPS, pharmaceutical drugs used for non-medical purposes (i.e. pain killers/analgesics, tranquilisers/sleeping pills, steroids, methadone or buprenorphine, other opiates/opioids combined), ketamine, GHB, tobacco (daily) and alcohol (weekly). The fit of each model was compared using MPlus 
version 7 (Muthén and Muthén, 2010). Following protocols adopted in past published latent class analyses (LCA) (Ramo et al., 2010), three criteria were used to assess model fit. The first criterion, the Lo-Mendell-Rubin adjusted log-likelihood ratio test (LMR-ALRT) statistic (Lo et al., 2001) was used to compare fit of a $k$ class model with a $k-1$ class model, with a low $p$ value $(<.050)$ indicating that the latter should be rejected in favour of the model with one additional class. The second and third criteria adopted were the Akaike's Information Criterion (AIC) and the Bayesian Information Criterion (sample-size adjusted; ssaBIC); these models balance likelihood and model fit, with lower values indicating better model fit. The third criterion, the entropy value, was an index of classification accuracy of the given classes, with higher values (range 0.0-1.0) indicating better differentiation of individuals into classes.

To address the second aim, correlates of latent class membership were analysed using bivariate and multivariable multinomial logistic regression conducted in SAS Version 9.4: correlates found to be significant $(p<.05)$ in the bivariate models were entered into the final multivariable model. Descriptive statistics comprised percentages for categorical data, means for normally distributed continuous variables, and medians for continuous data with significant positive skew and/or kurtosis.

Given this is a general population sample, both the LCA and regression analyses were conducted taking into account the effects of complex sampling methods. Data were weighted to correct for differential response rates and to account for over-sampling in some of the smaller jurisdictions. Strata and cluster variables were used in the analyses to account for the multilevel stratification of recruitment of the sample. For further information regarding these procedures please refer to the 2013 NDSHS technical report (Roy Morgan Research, 2014).

\section{Results}

\subsection{Sample characteristics}


Among the entire sample $(n=23,855)$, the most commonly used illicit substance was cannabis $(10.2 \%)$, followed by ecstasy (2.5\%), methamphetamine (2.1\%), cocaine $(2.1 \%)$, hallucinogens (1.3\%), SCRA $(1.2 \%)$, inhalants $(0.8 \%)$, NPS (excluding SCRA; $0.4 \%)$, ketamine $(0.3 \%)$, heroin $(0.1 \%)$ and GHB $(<0.1 \%)$. Non-medicinal pharmaceutical drug use in the preceding year was reported by $4.7 \%$ of the sample, with past-year alcohol use reported by the majority (78.3\%) of the sample. Very few participants ( $0.07 \%$ of entire sample; $5.7 \%$ of NPS consumers) reported use of SCRA and/or NPS but no other illicit substances.

Among those who reported past year use of any illicit substance $(n=3,309)$, the sample was predominantly male (59\%), with a mean age of 36 years. Participants were relatively well-educated: two-thirds (67\%) had completed a trade certificate or other educational qualification, although most (63\%) reported a gross (i.e. before tax) annual income of $<52,000$ AUD. Almost one-in-five participants (18\%) reported high levels of psychological distress, almost half (47\%) had engaged in some form of 'hazardous' behaviour (e.g. driving a vehicle, destroying property) while under the influence of alcohol and/or drugs, and one-third (34\%) reported that they had experienced difficulties ceasing their drug use in the past year.

\subsection{Model selection}

Examination of model fit statistics showed that AIC and ssaBIC was lowest for the 8-class model, whilst entropy was highest for the 2-class model (Table 3). Notably, the LMR-ALRT showed that the 6-class solution provided a significant improvement in fit over the 5 -class model, but the 7-class solution did not provide a significant improvement over the 6-class model, nor did the 8-class provide any significant improvement over the 7-class model. Examination of class composition alongside fit statistics further supported selection of the 6-class model: each class was substantive and clearly distinct in their patterns of drug use.

\subsection{Latent Class Probabilities and Class Definitions}


Response probabilities for each class are shown in Figure 1 (presented across two figures to facilitate ease of interpretation). Classes are described as follows: cannabis consumers (46\%) - comprising people who had a high probability of past year cannabis use (1.0) and a low probability of any other illicit drug use; pharmaceutical consumers (21\%) - comprising people who had a high probability of non-medicinal pharmaceutical drug use (1.0) and a low probability of any other illicit drug use; ecstasy and cocaine consumers (19\%) - comprising people who had a high probability of cocaine (0.50) and ecstasy (0.48) use, as well as cannabis (0.64) and weekly alcohol (0.73) use; and inhalant consumers (2\%) - comprising people who had a high probability of inhalant use (1.0) and a low probability of any other illicit drug use.

Two additional groups of note include: amphetamine and cannabis consumers (7\%) and polysubstance consumers $(6 \%)$. The former had a high probability of past year amphetamine $(0.58)$ and cannabis (0.82) use and daily tobacco (0.79) use, and the highest probability of SCRA use (0.35). The latter comprised people who had a high probability of past year use of multiple drugs. This group had the highest probability of past year ecstasy $(0.997)$, amphetamine $(0.71)$, cocaine $(0.61)$, hallucinogen (0.66), GHB and ketamine (0.26), and weekly alcohol use (0.79). This group also had the highest probability of other NPS use (0.31), and the second highest probability of SCRA use (0.31).

\subsection{Correlates of subgroup membership}

To determine if the consumer groups with the highest rates of NPS use differed from other illicit drug consumers, the bivariate and multinominal regression models were run with both amphetamine and cannabis consumers and polysubstance consumers as the referent categories (these two groups had the highest probability of SCRA and other NPS use). In both situations, all variables were found to be significant in the bivariate analyses (see Table 4 ) and were therefore included in the final multivariable multinomial regression models (see Table 2). Descriptive statistics for each group are outlined in Table 1. 
3.5 Multivariable Multinomial Regression Models

3.5.1 Amphetamine and cannabis consumers as the referent group

\subsubsection{Demographics}

Pharmaceutical consumers, inhalant consumers and cannabis consumers were significantly older than amphetamine and cannabis consumers, whilst polysubstance consumers were significantly younger. Pharmaceutical consumers had significantly lower odds of being unemployed and ecstasy and cocaine consumers had significantly lower odds of earning a gross annual income of $<\$ 52,000$, compared to the amphetamine and cannabis consumer group. All groups (except inhalant consumers) had significantly lower odds of residing in low SES areas, and inhalant consumers had significantly lower odds of reporting high levels of psychological distress, than amphetamine and cannabis consumers.

\subsubsection{Risk behaviours}

Pharmaceutical consumers, inhalant consumers and cannabis consumers had significantly lower odds of having engaged in dangerous activities while under the influence of drugs and/or alcohol in the past year, compared to amphetamine and cannabis consumers. Conversely, polysubstance consumers had significantly higher odds of having engaged in such activities. All groups had significantly lower odds of having had trouble ceasing their drug use in the past year compared to amphetamine and cannabis consumers. Inhalant consumers and cannabis consumers also had significantly lower odds of having injected any drug in the past year.

\subsubsection{Polysubstance consumers as the referent group}

\subsubsection{Demographics and mental health}

All groups were significantly older than polysubstance consumers, with pharmaceutical consumers also less likely to be male. Inhalant consumers and cannabis consumers had significantly lower odds 
of having completed a tertiary qualification, and cannabis consumers had significantly higher odds of having a gross annual income of $<\$ 52,000$, compared to polysubstance consumers. Amphetamine and cannabis consumers had significantly higher odds of residing in low SES areas.

\subsubsection{Alcohol and drug-related risk behaviours}

Cannabis consumers had significantly lower odds of scoring $\geq 9$ on the AUDIT-C, compared to polysubstance consumers. All groups had significantly lower odds of having engaged in dangerous activities while under the influence of drugs and/or alcohol in the past year, with cannabis consumers also having lower odds of having missed work or school due to their alcohol and drug use. As noted above, amphetamine and cannabis consumers had significantly higher odds of having had trouble ceasing their drug use in the past year, while pharmaceutical consumers had lower odds of trouble ceasing drug use. Both inhalant consumers and cannabis consumers had significantly lower odds of having injected any drug in the past year, compared to polysubstance consumers.

\section{Discussion}

We found that there was no distinct profile of exclusive SCRA or other NPS consumers, with very few participants ( $n=16 ; 5.7 \%$ of NPS consumers) reporting sole use of these substances. Rather, SCRA and NPS consumers mostly fell into the amphetamine and cannabis consumer and polysubstance consumer groups, respectively, providing support for the argument that most NPS consumers use a range of other illicit substances.

Polysubstance consumers (the group most likely to use NPS) were found to be significantly younger than all other groups, and were generally more educated, with few differences in terms of income or socio-economic status. They were also more likely to engage in a range of drug-related risk behaviours, including undertaking dangerous activities while under the influence of drugs and/or alcohol (most commonly driving a motor vehicle), injecting drugs and hazardous alcohol consumption. This suggests 
that polysubstance consumers are a high-risk taking group, regardless of their NPS use, and as such, may not need specific NPS interventions. Rather, existing harm reduction messages surrounding drug use (e.g. the dangers of mixing substances, driving while under the influence, safe injecting practices) could be tailored for poly drug consumers more generally.

Amphetamine and cannabis consumers (the group most likely to use SCRA) were also quite young, however were more disadvantaged in terms of socio-economic status. They were more likely than all other groups to report trouble ceasing their drug use. Given that persistent desire or repeated unsuccessful attempts to quit is one of the markers of substance use disorder (Hasin et al., 2013), it would seem that this is the group that may benefit most from treatment interventions. Indeed, existing treatment centres could incorporate the use of SCRA and other NPS into their screening/assessment processes, with treatment plans tailored accordingly. Amphetamine and cannabis consumers were also more likely than most other groups (excluding polysubstance and ecstasy and cocaine consumers) to engage in hazardous activity while under the influence of drugs and/or alcohol.

To date, responses to the NPS market have largely been regulatory (European Monitoring Centre for Drugs and Drug Addiction, 2016c), with uncertainty regarding the most appropriate health- and drugrelated interventions. More specifically, it has been unclear whether there needs to be specialised NPS interventions or harm reduction messages, and if so what these would look like. Our findings suggest that interventions could be based upon existing responses to drug use and targeted towards illicit drug consumers more generally. In contrast to Vreeker et al. (2017) (who concluded that NPS users may be considered a distinct group of users who need another approach in terms of prevention), we found that there was no distinct profile of NPS or SCRA consumers, at least in the Australian population, with the probability of use of these substances highest among amphetamine and cannabis consumers and polysubstance consumer groups - both of which were found to have higher rates of drug-related harms and/or risk behaviours. Indeed, it seems that the use of SCRA or other NPS may 
be indicative of more problematic patterns of drug use; a 'red flag' which could be easily assessed by health professionals working in the drug and alcohol field.

Furthermore, our findings suggest that NPS consumers are a heterogenous group. We found that people who had used SCRA in the past year were different to those who had used other forms of NPS. In particular, it appears that people who use SCRA may be more at risk of experiencing drug-related harms (e.g. dependence), whilst other NPS consumers may be more likely to engage in drug-related risk behaviours (e.g. driving while intoxicated). However, our ability to expand upon the heterogeneity of NPS consumers is limited by the fact that the NDSHS only breaks NPS down into two categories, when in fact there are different ways of categorising NPS (e.g. chemical group, effect on the central nervous system), and multiple possible classes within these approaches (European Monitoring Centre for Drugs and Drug Addiction, 2016a, The Drugs Wheel. A new model for substance awareness, 2018), with a lack of standardisation evident in the literature. It seems likely that there are further differences among NPS consumers that we have not been able to tease out (e.g. Sutherland et al., 2016) and as such, future research should examine whether correlates of use vary across NPS classes. It is also important for future research to consider differences within NPS classes, with our findings showing that people who reported SCRA use had almost equal probabilities of falling into the amphetamine and cannabis consumer and polysubstance consumer groups.

\subsection{Limitations and future research}

This study has certain limitations. Firstly, our findings are based on data from the 2013 NDSHS, as this was the first year to collect information on the use of NPS. In the intervening years, hundreds of additional NPS have been identified (265 from 2014-2016; European Monitoring Centre for Drugs and Drug Addiction, 2015, European Monitoring Centre for Drugs and Drug Addiction, 2016a, European Monitoring Centre for Drugs and Drug Addiction, 2017a), which may have changed the nature of the NPS market (although findings from the 2016 NDSHS show that past 12 month SCRA use has 
decreased, rather than increased; Australian Institute of Health \& Welfare, 2017). Furthermore, household surveys fail to capture certain populations (e.g. prisoners, homeless) which have been shown to have elevated rates of NPS use (Joseph et al., 2017, Ralphs et al., 2017), and as such our findings cannot be generalised to these populations. General population surveys must be accompanied by targeted surveys in order to adequately capture NPS use among marginalised, transient and institutionalized populations.

Secondly, analyses are reliant upon self-report data from participants which may be subject to bias. Although evidence points to sufficient validity and reliability of self-report in studies assessing illicit drug use (Darke, 1998), it is possible that people may have under-reported rates of use. This is compounded by the fact that definitions of NPS vary across countries and studies, and that the phrasing of questions can impact upon response options. For example, Palamar et al. (2017) found that 'gate' questions (which utilise skip logic, such that only a 'yes' response to use of a specific drug class will lead to more extensive queries of drug use in that class) resulted in lower response estimates than directly asking about specific NPS.

Furthermore, the data presented here refers to intentional NPS use only, and rates of 'unintentional' NPS consumption are likely much higher than reported. For example, wastewater analysis in Queensland detected a high frequency of methylone use (Thai et al., 2016), which was in contrast to low rates of reported use among sentinel samples of illicit drug consumers. Where possible, future studies should corroborate their findings through chemical analysis (e.g. Salomone et al., 2017). However, it should be noted that intentional and unintentional NPS use are distinct issues that require different harm reduction messages or interventions (e.g. unintentional use would be best addressed through interventions such as drug-testing and issuing health alerts when contaminants have been identified; Brunt et al., 2017). 
Although our findings show that most people who use SCRA or other NPS also use other illicit substances, it is unclear from this study which came first and it would be of benefit for future studies to explicitly explore this, through longitudinal analyses, or through surveys which specifically ask about age of initiation. Finally, there was a very small group of people $(n=16)$ who reported exclusive use of SCRA and/or other NPS, and it may be of benefit for future research to examine this group in more detail, although we acknowledge that, in the Australian context at least, such small numbers could limit the ability to do so. However, complex cultural and regulatory differences mean that there could be differing typologies of NPS consumers across countries (e.g. typologies may be markedly different in countries, such as Australia, where blanket bans have been introduced, prohibiting all NPS, compared to countries where NPS use is decriminalised and/or legal), and it would be of benefit for similar analyses to be conducted on general population data in other countries.

\section{Conclusions}

This study found no distinct profile of exclusive NPS consumers; rather the probability of SCRA and other NPS use was highest among amphetamine and cannabis consumers and polysubstance consumers. These groups reported the highest rates of drug-related harms (i.e. trouble ceasing use) and drug-related risk behaviours, respectively, suggesting that the use of SCRA or other NPS could be indicative of patterns of problematic drug use. These findings suggest that there may not need to be specialised NPS interventions or harm reduction messages; rather, they could be built into existing responses to drug use and targeted towards illicit drug consumers more generally. 
Figure 1: Past 12-month licit and illicit drug use according to group for the 6-class solution 


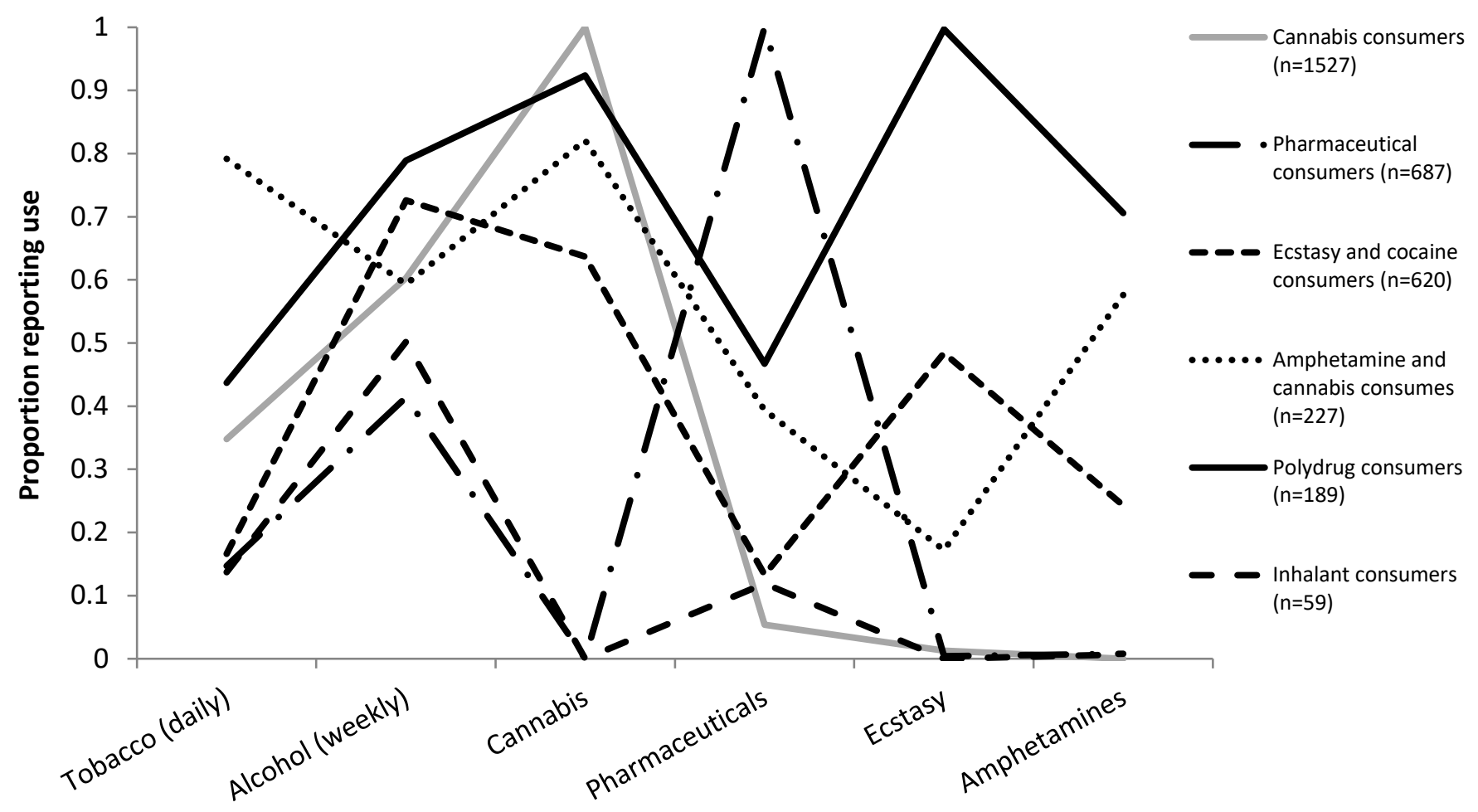


Figure 1 (continued): Past 12-month licit and illicit drug use according to group for the 6-class solution 


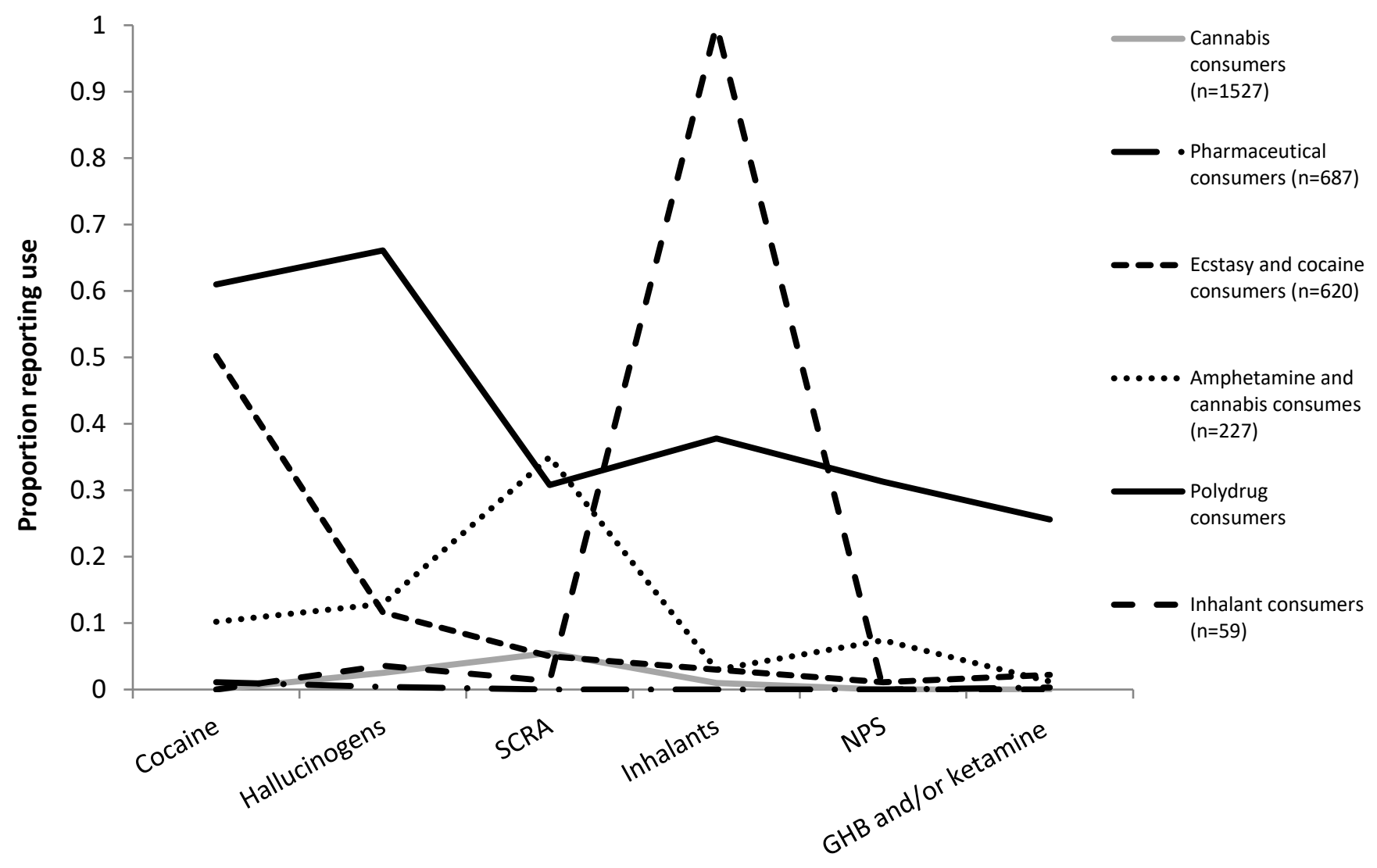


Table 1: Demographics and risk behaviours according to group

\begin{tabular}{|c|c|c|c|c|c|c|c|c|}
\hline & $\begin{array}{l}\text { People who } \\
\text { had not } \\
\text { consumed } \\
\text { any illicit } \\
\text { substance } \\
\mathrm{N}=20,024\end{array}$ & $\begin{array}{l}\text { People who } \\
\text { had } \\
\text { consumed } \\
\text { an illicit } \\
\text { substance/s } \\
\mathrm{N}=3309\end{array}$ & $\begin{array}{c}\text { Cannabis } \\
\text { consumers } \\
n=1541\end{array}$ & $\begin{array}{l}\text { Pharmaceutical } \\
\text { consumers } \\
n=762\end{array}$ & $\begin{array}{c}\text { Ecstasy and } \\
\text { cocaine } \\
\text { consumers } \\
n=571\end{array}$ & $\begin{array}{c}\text { Amphetamine } \\
\text { and cannabis } \\
\text { consumers } \\
n=212\end{array}$ & $\begin{array}{l}\text { Polysubstance } \\
\text { consumers } \\
n=150\end{array}$ & $\begin{array}{c}\text { Inhalant } \\
\text { consumers } \\
n=73\end{array}$ \\
\hline \multicolumn{9}{|l|}{ Demographics and Mental Health: } \\
\hline Mean age (years) & 44.6 & 36.3 & 34.6 & 48.5 & 30.5 & 30.6 & 26.6 & 55.2 \\
\hline Male \% & 47.8 & 59.4 & 61.4 & 48.4 & 62.6 & 61.6 & 70.0 & 61.8 \\
\hline $\begin{array}{l}\text { Completed trade or other } \\
\text { educational qualification \% }\end{array}$ & 63.4 & 66.9 & 64.9 & 65.1 & 75.9 & 56.3 & 77.3 & 54.2 \\
\hline Unemployed \% & 6.4 & 10.2 & 10.6 & 6.8 & 7.8 & 19.0 & 15.4 & 11.9 \\
\hline Gross annual income $<\$ 52,000 \%$ & 62.3 & 63.3 & 66.0 & 63.1 & 53.9 & 75.6 & 61.3 & 59.5 \\
\hline Low SES \% & 36.6 & 38.0 & 39.9 & 41.6 & 25.7 & 52.5 & 28.5 & 49.2 \\
\hline K10 score $\geq 22 \%$ & 9.2 & 18.4 & 15.9 & 20.0 & 16.4 & 33.5 & 24.3 & 9.1 \\
\hline \multicolumn{9}{|l|}{ Risk Behaviours: } \\
\hline AUDIT-C score $\geq 9 \%$ & & 17.5 & 14.8 & 6.4 & 24.9 & 27.4 & 35.9 & 7.1 \\
\hline $\begin{array}{l}\text { Dangerous activity whilst under } \\
\text { AOD influence past year } \%\end{array}$ & & 46.5 & 45.3 & 18.9 & 58.4 & 74.4 & 84.5 & 22.9 \\
\hline $\begin{array}{l}\text { Missed } \\
\text { work/school/TAFE/university for } \\
\text { AOD reason in past } 3 \text { months \% }\end{array}$ & & 9.7 & 7.0 & 3.9 & 13.6 & 14.5 & 26.9 & 2.4 \\
\hline
\end{tabular}




\begin{tabular}{|c|c|c|c|c|c|c|c|}
\hline $\begin{array}{l}\text { Trouble ceasing drug use in past } \\
\text { year } \%\end{array}$ & 33.8 & 31.7 & 25.8 & 29.0 & 72.3 & 49.9 & 20.6 \\
\hline Injected any drug (past year) \% & 2.1 & 0.5 & 0.7 & 1.3 & 13.8 & 8.9 & 0 \\
\hline Daily cannabis & 8.8 & 10.9 & 0 & 4.5 & 29.9 & 15.1 & 0 \\
\hline Weekly or more meth & 2.2 & 0 & 0 & 2.4 & 18.5 & 8.7 & 0 \\
\hline
\end{tabular}

Note: Figures for amphetamine and cannabis consumers, and polysubstance consumers, are bolded since they are the two referent categories (i.e. these two groups have the highest probability of SCRA and other NPS use). AUDIT-C: Alcohol Use Disorders Identification Test; K10: Kessler Psychological Distress Scale; SES: socio-economic status. 
Table 2: Demographics and risk behaviours according to group, with polysubstance consumers and amphetamine and cannabis consumers as the referent groups: Multivariable models.

\begin{tabular}{|c|c|c|c|c|c|c|c|c|c|c|}
\hline & \multicolumn{5}{|c|}{ Polysubstance consumers vs. } & \multicolumn{5}{|c|}{ Amphetamine and cannabis consumers vs. } \\
\hline Outcome & $\begin{array}{c}\text { Cannabis } \\
\text { consumers } \\
\text { AOR } \\
(95 \% \mathrm{Cl} ; p)\end{array}$ & $\begin{array}{c}\text { Pharmaceutical } \\
\text { consumers } \\
\text { AOR } \\
(95 \% \mathrm{Cl} ; p)\end{array}$ & $\begin{array}{l}\text { Ecstasy and } \\
\text { cocaine } \\
\text { consumers } \\
\text { AOR } \\
(95 \% \mathrm{Cl} ; p)\end{array}$ & $\begin{array}{c}\text { Amphetamine } \\
\text { and cannabis } \\
\text { consumers } \\
\text { AOR } \\
(95 \% \mathrm{Cl} ; p)\end{array}$ & $\begin{array}{c}\text { Inhalant } \\
\text { consumers } \\
\text { AOR } \\
(95 \% \mathrm{Cl} ; p)\end{array}$ & $\begin{array}{c}\text { Cannabis } \\
\text { consumers } \\
\text { AOR } \\
(95 \% \mathrm{Cl} ; p)\end{array}$ & $\begin{array}{c}\text { Pharmaceutical } \\
\text { consumers } \\
\text { AOR } \\
(95 \% \mathrm{Cl} ; p)\end{array}$ & $\begin{array}{c}\text { Ecstasy and } \\
\text { cocaine } \\
\text { consumers } \\
\text { AOR } \\
(95 \% \mathrm{Cl} ; p)\end{array}$ & $\begin{array}{c}\text { Polysubstance } \\
\text { consumer } \\
\text { AOR } \\
(95 \% \mathrm{Cl} ; p)\end{array}$ & $\begin{array}{c}\text { Inhalant } \\
\text { consumers } \\
\text { AOR } \\
(95 \% \mathrm{Cl} ; p)\end{array}$ \\
\hline Demographics and Mental Health & & & & & & & & & & \\
\hline Mean age (years) & $\begin{array}{c}1.09(1.06- \\
1.12)^{* * *}\end{array}$ & $\begin{array}{c}1.12(1.09- \\
1.16)^{* * *}\end{array}$ & $\begin{array}{c}1.04(1.01- \\
1.08 ; 0.006)^{* *}\end{array}$ & $\begin{array}{c}1.05(1.02- \\
1.09 ; 0.004)^{* *}\end{array}$ & $\begin{array}{c}1.13(1.07- \\
1.18)^{* * *}\end{array}$ & $\begin{array}{c}1.03(1.01- \\
1.06 \\
0.006)^{* *}\end{array}$ & $\begin{array}{c}1.07(1.04- \\
1.10)^{* * *}\end{array}$ & $\begin{array}{l}0.99(0.97- \\
1.02 ; 0.57)\end{array}$ & $\begin{array}{c}0.95(0.92- \\
0.98 ; 0.004)^{* *}\end{array}$ & $\begin{array}{c}1.07(1.02- \\
1.12 ; 0.004)^{* *}\end{array}$ \\
\hline Male $\%$ & $\begin{array}{l}0.77(0.42- \\
1.42 ; 0.41)\end{array}$ & $\begin{array}{c}0.39(0.20- \\
0.78 ; 0.008)^{* *}\end{array}$ & $\begin{array}{l}0.66(0.35- \\
1.24 ; 0.19)\end{array}$ & $\begin{array}{l}0.71(0.33- \\
1.53 ; 0.38)\end{array}$ & $\begin{array}{l}0.64(0.17- \\
2.49 ; 0.52)\end{array}$ & $\begin{array}{l}1.09(0.61- \\
1.95 ; 0.77)\end{array}$ & $\begin{array}{c}0.55(0.28-1.08 \\
0.08)\end{array}$ & $\begin{array}{l}0.93(0.49- \\
1.74 ; 0.82)\end{array}$ & $\begin{array}{l}1.41(0.65- \\
3.04 ; 0.38)\end{array}$ & $\begin{array}{l}0.90(0.23- \\
3.55 ; 0.89)\end{array}$ \\
\hline Completed trade/qualification \% & $\begin{array}{c}0.40(0.19- \\
0.83 ; 0.01)^{*}\end{array}$ & $\begin{array}{l}0.49(0.21- \\
1.11 ; 0.09)\end{array}$ & $\begin{array}{l}0.56(0.26- \\
1.22 ; 0.15)\end{array}$ & $\begin{array}{l}0.42(0.16- \\
1.11 ; 0.08)\end{array}$ & $\begin{array}{c}0.21(0.05- \\
0.83 ; 0.03)^{*}\end{array}$ & $\begin{array}{l}0.93(0.48- \\
1.81 ; 0.84)\end{array}$ & $\begin{array}{c}1.15(0.54-2.44 \\
0.72)\end{array}$ & $\begin{array}{l}1.33(0.65- \\
2.70 ; 0.43)\end{array}$ & $\begin{array}{l}2.36(0.90- \\
6.19 ; 0.08)\end{array}$ & $\begin{array}{l}0.50(0.13- \\
1.94 ; 0.32)\end{array}$ \\
\hline Unemployed \% & $\begin{array}{l}0.56(0.18- \\
1.74 ; 0.32)\end{array}$ & $\begin{array}{c}0.18(0.04- \\
0.78 ; 0.02)^{*}\end{array}$ & $\begin{array}{l}0.29(0.07- \\
1.14 ; 0.08)\end{array}$ & $\begin{array}{l}0.77(0.17- \\
3.44 ; 0.74)\end{array}$ & $\begin{array}{c}3.60(0.53- \\
24.65 ; 0.19)\end{array}$ & $\begin{array}{l}0.73(0.25- \\
2.12 ; 0.56)\end{array}$ & $\begin{array}{c}0.23(0.05-0.98 \\
0.046)^{*}\end{array}$ & $\begin{array}{l}0.37(0.09- \\
1.50 ; 0.16)\end{array}$ & $\begin{array}{l}1.29(0.29- \\
5.73 ; 0.74)\end{array}$ & $\begin{array}{c}4.65(0.70- \\
31.10 ; 0.11)\end{array}$ \\
\hline Gross annual income $<\$ 52,000 \%$ & $\begin{array}{c}2.00(1.10- \\
3.64 ; 0.02)^{*}\end{array}$ & $\begin{array}{l}1.16(0.59- \\
2.31 ; 0.67)\end{array}$ & $\begin{array}{l}0.88(0.46- \\
1.68 ; 0.69)\end{array}$ & $\begin{array}{l}2.05(0.92- \\
4.55 ; 0.08)\end{array}$ & $\begin{array}{l}1.09(0.31- \\
3.83 ; 0.90)\end{array}$ & $\begin{array}{l}0.98(0.53- \\
1.78 ; 0.94)\end{array}$ & $\begin{array}{c}0.57(0.28-1.15 \\
0.11)\end{array}$ & $\begin{array}{c}0.43(0.23- \\
0.81 ; 0.009)^{* *}\end{array}$ & $\begin{array}{l}0.49(0.22- \\
1.09 ; 0.08)\end{array}$ & $\begin{array}{l}0.53(0.15- \\
1.89 ; 0.33)\end{array}$ \\
\hline Low SES \% & $\begin{array}{l}1.09(0.61- \\
1.93 ; 0.78)\end{array}$ & $\begin{array}{l}1.04(0.53- \\
2.04 ; 0.91)\end{array}$ & $\begin{array}{l}0.73(0.40- \\
1.34 ; 0.31)\end{array}$ & $\begin{array}{c}2.30(1.11- \\
4.77 ; 0.03)^{*}\end{array}$ & $\begin{array}{l}1.71(0.48- \\
6.12 ; 0.41)\end{array}$ & $\begin{array}{c}0.47(0.27- \\
0.85 ; 0.01)^{*}\end{array}$ & $\begin{array}{c}0.45(0.23-0.89 \\
0.02)^{*}\end{array}$ & $\begin{array}{c}0.32(0.17- \\
0.59)^{* * *}\end{array}$ & $\begin{array}{c}0.44(0.21- \\
0.91 ; 0.03)^{*}\end{array}$ & $\begin{array}{l}0.75(0.21- \\
2.62 ; 0.65)\end{array}$ \\
\hline K10 score $\geq 22 \%$ & $\begin{array}{l}0.94(0.46- \\
1.90 ; 0.86)\end{array}$ & $\begin{array}{l}1.74(0.75- \\
4.05 ; 0.20)\end{array}$ & $\begin{array}{l}0.94(0.46- \\
1.93 ; 0.87)\end{array}$ & $\begin{array}{l}1.48(0.64- \\
3.43 ; 0.36)\end{array}$ & $\begin{array}{l}0.13(0.01- \\
1.49 ; 0.10)\end{array}$ & $\begin{array}{l}0.64(0.33- \\
1.22 ; 0.17)\end{array}$ & $\begin{array}{c}1.18(0.52-2.65 \\
0.70)\end{array}$ & $\begin{array}{l}0.64(0.31- \\
1.29 ; 0.21)\end{array}$ & $\begin{array}{l}0.68(0.29- \\
1.56 ; 0.36)\end{array}$ & $\begin{array}{c}0.09(0.01- \\
0.99 ; 0.049)^{*}\end{array}$ \\
\hline Risk Behaviours: & & & & & & & & & & \\
\hline
\end{tabular}




\begin{tabular}{|c|c|c|c|c|c|c|c|c|c|c|}
\hline AUDIT-C score $\geq 9 \%$ & $\begin{array}{c}0.54(0.29- \\
0.99 ; 0.04)^{*}\end{array}$ & $\begin{array}{l}0.45(0.19- \\
1.04 ; 0.06)\end{array}$ & $\begin{array}{l}0.79(0.42- \\
1.48 ; 0.45)\end{array}$ & $\begin{array}{l}0.55(0.24- \\
1.23 ; 0.15)\end{array}$ & $\begin{array}{l}0.53(0.09- \\
3.29 ; 0.50)\end{array}$ & $\begin{array}{l}0.98(0.51- \\
1.89 ; 0.95)\end{array}$ & $\begin{array}{c}0.81(0.33-2.02 \\
0.66)\end{array}$ & $\begin{array}{l}1.44(0.71- \\
2.89 ; 0.31)\end{array}$ & $\begin{array}{l}1.83(0.81- \\
4.12 ; 0.15)\end{array}$ & $\begin{array}{l}0.97(0.15- \\
6.14 ; 0.98)\end{array}$ \\
\hline $\begin{array}{l}\text { Dangerous activity whilst under AOD } \\
\text { influence past year \% }\end{array}$ & $\begin{array}{c}0.14(0.06- \\
0.33)^{* * *}\end{array}$ & $\begin{array}{c}0.07(0.03- \\
0.16)^{* * *}\end{array}$ & $\begin{array}{c}0.23(0.10- \\
0.54)^{* * *}\end{array}$ & $\begin{array}{l}0.32(0.12- \\
0.86 ; 0.02)^{*}\end{array}$ & $\begin{array}{c}0.08(0.02- \\
0.35)^{* * *}\end{array}$ & $\begin{array}{l}0.45(0.24- \\
0.85 ; 0.01)^{*}\end{array}$ & $\begin{array}{c}0.22(0.11- \\
0.43)^{* * *}\end{array}$ & $\begin{array}{l}0.72(0.37- \\
1.43 ; 0.35)\end{array}$ & $\begin{array}{l}3.18(1.16- \\
8.67 ; 0.02)^{*}\end{array}$ & $\begin{array}{c}0.26(0.07- \\
0.99 ; 0.049)^{*}\end{array}$ \\
\hline $\begin{array}{l}\text { Missed work/school/TAFE/university } \\
\text { for AOD reason in past } 3 \text { months } \%\end{array}$ & $\begin{array}{l}0.38(0.18- \\
0.79 ; 0.01)^{*}\end{array}$ & $\begin{array}{l}0.42(0.15- \\
1.15 ; 0.09)\end{array}$ & $\begin{array}{l}0.68(0.32- \\
1.44 ; 0.32)\end{array}$ & $\begin{array}{l}0.57(0.21- \\
1.53 ; 0.27)\end{array}$ & $\begin{array}{l}0.40(0.04- \\
3.64 ; 0.42)\end{array}$ & $\begin{array}{l}0.66(0.29- \\
1.49 ; 0.32)\end{array}$ & $\begin{array}{c}0.72(0.25-2.09 \\
0.55)\end{array}$ & $\begin{array}{l}1.19(0.50- \\
2.85 ; 0.70)\end{array}$ & $\begin{array}{l}1.75(0.65- \\
4.67 ; 0.27)\end{array}$ & $\begin{array}{l}0.70(0.08- \\
6.45 ; 0.75)\end{array}$ \\
\hline $\begin{array}{l}\text { Trouble ceasing drug use in past year } \\
\%\end{array}$ & $\begin{array}{l}0.61(0.32- \\
1.14 ; 0.12)\end{array}$ & $\begin{array}{c}0.36(0.17- \\
0.75 ; 0.007)^{* *}\end{array}$ & $\begin{array}{l}0.55(0.29- \\
1.05 ; 0.07)\end{array}$ & $\begin{array}{c}3.54(1.55- \\
8.09 ; 0.003)^{* *}\end{array}$ & $\begin{array}{l}0.23(0.05- \\
1.14 ; 0.07)\end{array}$ & $\begin{array}{c}0.17(0.09- \\
0.33)^{* * *}\end{array}$ & $\begin{array}{c}0.10(0.05- \\
0.22)^{* * *}\end{array}$ & $\begin{array}{c}0.16(0.08- \\
0.32)^{* * *}\end{array}$ & $\begin{array}{c}0.28(0.12- \\
0.65 ; 0.003)^{* *}\end{array}$ & $\begin{array}{c}0.07(0.01- \\
0.32)^{* * *}\end{array}$ \\
\hline Injected any drug in past year \% & $\begin{array}{c}0.02(0.004- \\
0.11)^{* * *}\end{array}$ & $\begin{array}{l}0.09(0.01- \\
1.00 ; 0.05)\end{array}$ & $\begin{array}{l}0.18(0.02- \\
1.66 ; 0.13)\end{array}$ & $\begin{array}{l}0.32(0.08- \\
1.24 ; 0.10)\end{array}$ & $<0.001 * * *$ & $\begin{array}{c}0.06(0.01- \\
0.36 \\
0.002)^{* *}\end{array}$ & $\begin{array}{c}0.29(0.03-2.75 \\
0.28)\end{array}$ & $\begin{array}{l}0.57(0.07- \\
4.37 ; 0.59)\end{array}$ & $\begin{array}{c}3.11(0.81- \\
11.94 ; 0.10)\end{array}$ & $<0.001 * * *$ \\
\hline
\end{tabular}

Note. An odds ratio (OR) or adjusted odds ratio (AOR) of 1 indicates the event is equally probable in each group, $>1$ indicates the event is more likely to occur in the nonreference group relative to the reference group, and $<1$ indicates the event is less likely to occur in the non-reference group relative to the reference group. ${ }^{*} p<.050 ; * * p<.010 ;{ }^{* * *} p<.001$; exact $p$ values not presented where $<0.001$.

Cl: confidence interval; AOD: alcohol and/or drugs; AUDIT-C: Alcohol Use Disorders Identification Test; K10: Kessler Psychological Distress Scale; SES: socio-economic status. 


\section{SUPPLEMENTARY MATERIALS}

Table S3: Latent Class Fit Statistics for models with 1 to 8 classes for licit and illicit drug use variables ( $\mathrm{n}=3309)$

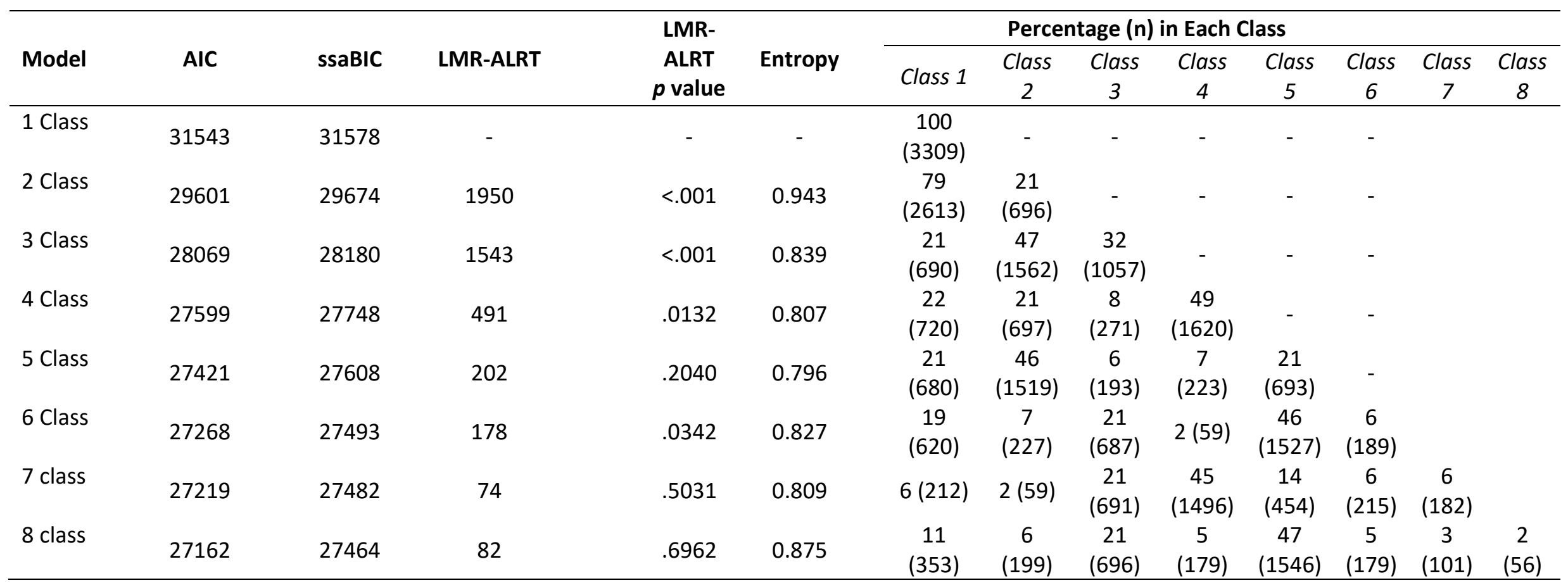

Note. AIC: Akaike Information Criterion; ssaBIC: sample-size adjusted Bayesian Information Criterion; LMR-ALRT: Lo-Mendell-Rubin Adjusted Likelihood Ratio Test. 
Table S4: Demographics and risk behaviours according to group, with polysubstance consumers and amphetamine and cannabis consumers as the referent groups: Bivariate models.

\begin{tabular}{|c|c|c|c|c|c|c|c|c|c|c|}
\hline & \multicolumn{5}{|c|}{ Polysubstance consumers vs. } & \multicolumn{5}{|c|}{ Amphetamine and cannabis consumers vs. } \\
\hline Outcome & $\begin{array}{c}\text { Cannabis } \\
\text { consumers } \\
\text { OR } \\
(95 \% \mathrm{Cl} ; p)\end{array}$ & $\begin{array}{c}\text { Pharmaceutical } \\
\text { consumers } \\
\text { OR } \\
(95 \% \mathrm{Cl} ; p)\end{array}$ & $\begin{array}{c}\text { Ecstasy and } \\
\text { cocaine } \\
\text { consumers } \\
\text { OR } \\
(95 \% \mathrm{Cl} ; p)\end{array}$ & $\begin{array}{c}\text { Amphetamine } \\
\text { and cannabis } \\
\text { consumers } \\
\text { OR } \\
(95 \% \mathrm{Cl} ; p)\end{array}$ & $\begin{array}{c}\text { Inhalant } \\
\text { consumers OR } \\
(95 \% \mathrm{Cl} ; p)\end{array}$ & $\begin{array}{c}\text { Cannabis } \\
\text { consumers } \\
\text { OR } \\
(95 \% \mathrm{Cl} ; p)\end{array}$ & $\begin{array}{c}\text { Pharmaceutical } \\
\text { consumers } \\
\text { OR } \\
(95 \% \mathrm{Cl} ; p)\end{array}$ & $\begin{array}{l}\text { Ecstasy and } \\
\text { cocaine } \\
\text { consumers } \\
\text { OR } \\
(95 \% \mathrm{Cl} ; p)\end{array}$ & $\begin{array}{c}\text { Polysubstance } \\
\text { consumers OR } \\
(95 \% \mathrm{Cl} ; p)\end{array}$ & $\begin{array}{c}\text { Inhalant } \\
\text { consumers } \\
\text { OR } \\
(95 \% \mathrm{Cl} ; p)\end{array}$ \\
\hline Demographics and Mental Health & & & & & & & & & & \\
\hline Mean age (years) & $\begin{array}{c}1.06(1.04- \\
1.07)^{* * *}\end{array}$ & $\begin{array}{c}1.11(1.10- \\
1.13)^{* * *}\end{array}$ & $\begin{array}{c}1.03(1.02- \\
1.05)^{* * *}\end{array}$ & $\begin{array}{c}1.03(1.02- \\
1.05)^{* * *}\end{array}$ & $\begin{array}{c}1.14(1.11- \\
1.17)^{* * *}\end{array}$ & $\begin{array}{c}1.02(1.01- \\
1.04)^{* * *}\end{array}$ & $\begin{array}{c}1.08(1.06- \\
1.09)^{* * *}\end{array}$ & $\begin{array}{l}1.00(0.99- \\
1.01 ; 0.90)\end{array}$ & $\begin{array}{c}0.97(0.95- \\
0.98)^{* * *}\end{array}$ & $\begin{array}{c}1.10(1.07- \\
1.13)^{* * *}\end{array}$ \\
\hline Male $\%$ & $\begin{array}{l}0.68(0.44- \\
1.07 ; 0.09)\end{array}$ & $\begin{array}{c}0.40(0.25- \\
0.64)^{* * *}\end{array}$ & $\begin{array}{l}0.72(0.45- \\
1.15 ; 0.17)\end{array}$ & $\begin{array}{l}0.69(0.41- \\
1.16 ; 0.16)\end{array}$ & $\begin{array}{l}0.69(0.34- \\
1.43 ; 0.32)\end{array}$ & $\begin{array}{l}0.99(0.71- \\
1.37 ; 0.95)\end{array}$ & $\begin{array}{c}0.58(0.41-0.84 \\
0.004)^{* *}\end{array}$ & $\begin{array}{l}1.04(0.71- \\
1.54 ; 0.83)\end{array}$ & $\begin{array}{l}1.45(0.86- \\
2.44 ; 0.16)\end{array}$ & $\begin{array}{l}1.01(0.52- \\
1.94 ; 0.99)\end{array}$ \\
\hline Completed trade/qualification \% & $\begin{array}{c}0.55(0.34- \\
0.88 ; 0.01)^{*}\end{array}$ & $\begin{array}{c}0.56(0.34-0.90 \\
0.02)^{*}\end{array}$ & $\begin{array}{l}0.93(0.56- \\
1.55 ; 0.78)\end{array}$ & $\begin{array}{c}0.38(0.20- \\
0.69 ; 0.002)^{* *}\end{array}$ & $\begin{array}{c}0.36(0.17- \\
0.75 ; 0.006)^{* *}\end{array}$ & $\begin{array}{l}1.46(0.97- \\
2.19 ; 0.07)\end{array}$ & $\begin{array}{c}1.48(0.97-2.27 \\
0.07)\end{array}$ & $\begin{array}{c}2.47(1.56- \\
3.90)^{* * *}\end{array}$ & $\begin{array}{c}2.66(1.44- \\
4.89 ; 0.002)^{* *}\end{array}$ & $\begin{array}{l}0.96(0.48- \\
1.93 ; 0.90)\end{array}$ \\
\hline Unemployed \% & $\begin{array}{l}0.65(0.34- \\
1.26 ; 0.20)\end{array}$ & $\begin{array}{c}0.40(0.19-0.84 \\
0.02)^{*}\end{array}$ & $\begin{array}{c}0.47(0.22- \\
0.97 ; 0.04)^{*}\end{array}$ & $\begin{array}{l}1.29(0.60- \\
2.78 ; 0.52)\end{array}$ & $\begin{array}{l}0.74(0.19- \\
2.99 ; 0.68)\end{array}$ & $\begin{array}{c}0.51(0.31- \\
0.83 \\
0.007)^{* *}\end{array}$ & $\begin{array}{c}0.31(0.17- \\
0.57)^{* * *}\end{array}$ & $\begin{array}{c}0.36(0.20- \\
0.66)^{* * *}\end{array}$ & $\begin{array}{l}0.78(0.36- \\
1.68 ; 0.52)\end{array}$ & $\begin{array}{l}0.58(0.15- \\
2.20 ; 0.42)\end{array}$ \\
\hline Gross annual income $<\$ 52,000 \%$ & $\begin{array}{l}1.23(0.77- \\
1.95 ; 0.39)\end{array}$ & $\begin{array}{c}1.08(0.66-1.76 \\
0.76)\end{array}$ & $\begin{array}{l}0.74(0.45- \\
1.22 ; 0.23)\end{array}$ & $\begin{array}{c}1.96(1.03- \\
3.74 ; 0.04)^{*}\end{array}$ & $\begin{array}{l}0.93(0.40- \\
2.18 ; 0.87)\end{array}$ & $\begin{array}{c}0.62(0.41- \\
0.94 ; 0.02)^{*}\end{array}$ & $\begin{array}{c}0.55(0.35-0.87 \\
0.01)^{* *}\end{array}$ & $\begin{array}{c}0.38(0.24- \\
0.59)^{* * *}\end{array}$ & $\begin{array}{c}0.51(0.27- \\
0.97 ; 0.04)^{*}\end{array}$ & $\begin{array}{l}0.47(0.20- \\
1.11 ; 0.08)\end{array}$ \\
\hline Low SES \% & $\begin{array}{c}1.66(1.07- \\
2.57 ; 0.02)^{*}\end{array}$ & $\begin{array}{c}1.79(1.12-2.84 \\
0.01)^{*}\end{array}$ & $\begin{array}{l}0.86(0.55- \\
1.37 ; 0.53)\end{array}$ & $\begin{array}{c}2.77(1.63- \\
4.70)^{* * *}\end{array}$ & $\begin{array}{c}2.42(1.15- \\
5.10 ; 0.02)^{*}\end{array}$ & $\begin{array}{c}0.60(0.42- \\
0.86 \\
0.005)^{* *}\end{array}$ & $\begin{array}{c}0.64(0.43-0.96 \\
0.03)^{*}\end{array}$ & $\begin{array}{c}0.31(0.21- \\
0.47)^{* * *}\end{array}$ & $\begin{array}{c}0.36(0.21- \\
0.61)^{* * *}\end{array}$ & $\begin{array}{l}0.87(0.43- \\
1.77 ; 0.71)\end{array}$ \\
\hline K10 score $\geq 22 \%$ & $\begin{array}{c}0.59(0.37- \\
0.93 ; 0.02)^{*}\end{array}$ & $\begin{array}{c}0.78(0.49-1.24 \\
0.29)\end{array}$ & $\begin{array}{c}0.61(0.38- \\
0.98 ; 0.04)^{*}\end{array}$ & $\begin{array}{l}1.57(0.90- \\
2.75 ; 0.11)\end{array}$ & $\begin{array}{c}0.31(0.12- \\
0.84 ; 0.02)^{*}\end{array}$ & $\begin{array}{c}0.38(0.25- \\
0.56)^{* * *}\end{array}$ & $\begin{array}{c}0.50(0.32-0.77 \\
0.002)^{* *}\end{array}$ & $\begin{array}{c}0.39(0.25- \\
0.61)^{* * *}\end{array}$ & $\begin{array}{l}0.64(0.36- \\
1.12 ; 0.11)\end{array}$ & $\begin{array}{c}0.20(0.08- \\
0.52 ; 0.001)^{* *}\end{array}$ \\
\hline
\end{tabular}




\begin{tabular}{|c|c|c|c|c|c|c|c|c|c|c|}
\hline Risk Behaviours: & & & & & & & & & & \\
\hline AUDIT-C score $\geq 9 \%$ & $\begin{array}{c}0.31(0.20- \\
0.49)^{* * *}\end{array}$ & $\begin{array}{l}0.12(0.07- \\
0.22)^{* * *}\end{array}$ & $\begin{array}{l}0.59(0.37- \\
0.95 ; 0.03)^{*}\end{array}$ & $\begin{array}{l}0.67(0.39- \\
1.18 ; 0.17)\end{array}$ & $\begin{array}{c}0.14(0.04- \\
0.50 ; 0.003)^{* *}\end{array}$ & $\begin{array}{l}0.46(0.30- \\
0.71)^{* * *}\end{array}$ & $\begin{array}{l}0.18(0.10- \\
0.33)^{* * *}\end{array}$ & $\begin{array}{l}0.88(0.55- \\
1.41 ; 0.60)\end{array}$ & $\begin{array}{l}1.49(0.85- \\
2.60 ; 0.17)\end{array}$ & $\begin{array}{l}0.20(0.06- \\
0.75 ; 0.02)^{*}\end{array}$ \\
\hline $\begin{array}{l}\text { Dangerous activity whilst under AOD } \\
\text { influence past year \% }\end{array}$ & $\begin{array}{l}0.15(0.09- \\
0.27)^{* * *}\end{array}$ & $\begin{array}{l}0.04(0.02- \\
0.08)^{* * *}\end{array}$ & $\begin{array}{c}0.26(0.14- \\
0.47)^{* * *}\end{array}$ & $\begin{array}{l}0.53(0.27- \\
1.05 ; 0.07)\end{array}$ & $\begin{array}{l}0.05(0.02- \\
0.14)^{* * *}\end{array}$ & $\begin{array}{l}0.29(0.19- \\
0.42)^{* * *}\end{array}$ & $\begin{array}{l}0.08(0.05- \\
0.13)^{* * *}\end{array}$ & $\begin{array}{l}0.48(0.32- \\
0.74)^{* * *}\end{array}$ & $\begin{array}{l}1.88(0.95- \\
3.72 ; 0.07)\end{array}$ & $\begin{array}{l}0.10(0.05- \\
0.23)^{* * *}\end{array}$ \\
\hline $\begin{array}{l}\text { Missed work/school/TAFE/uni for } \\
\text { AOD reason in past } 3 \text { months } \%\end{array}$ & $\begin{array}{c}0.21(0.12- \\
0.35)^{* * *}\end{array}$ & $\begin{array}{c}0.11(0.06- \\
0.22)^{* * *}\end{array}$ & $\begin{array}{c}0.43(0.25- \\
0.74 \\
0.003)^{* *}\end{array}$ & $\begin{array}{c}0.46(0.23- \\
0.91 ; 0.03)^{*}\end{array}$ & $\begin{array}{c}0.07(0.01- \\
0.52 ; 0.01)^{*}\end{array}$ & $\begin{array}{c}0.45(0.24- \\
0.83 ; 0.01)^{*}\end{array}$ & $\begin{array}{c}0.24(0.11- \\
0.52)^{* * *}\end{array}$ & $\begin{array}{l}0.93(0.50- \\
1.71 ; 0.80)\end{array}$ & $\begin{array}{l}2.17(1.09- \\
4.30 ; 0.03)^{*}\end{array}$ & $\begin{array}{l}0.14(0.02- \\
1.15 ; 0.07)\end{array}$ \\
\hline $\begin{array}{l}\text { Trouble ceasing drug use in past year } \\
\%\end{array}$ & $\begin{array}{l}0.47(0.30- \\
0.73)^{* * *}\end{array}$ & $\begin{array}{l}0.35(0.22- \\
0.56)^{* * *}\end{array}$ & $\begin{array}{l}0.41(0.25- \\
0.67)^{* * *}\end{array}$ & $\begin{array}{c}2.63(1.47- \\
4.70 ; 0.001)^{* *}\end{array}$ & $\begin{array}{c}0.26(0.11- \\
0.60 ; 0.002)^{* *}\end{array}$ & $\begin{array}{l}0.18(0.12- \\
0.27)^{* * *}\end{array}$ & $\begin{array}{l}0.13(0.09- \\
0.21)^{* * *}\end{array}$ & $\begin{array}{l}0.16(0.10- \\
0.25)^{* * *}\end{array}$ & $\begin{array}{c}0.38(0.21- \\
0.68 ; 0.001)^{* *}\end{array}$ & $\begin{array}{l}0.10(0.04- \\
0.22)^{* * *}\end{array}$ \\
\hline Injected any drug in past year \% & $\begin{array}{l}0.05(0.02- \\
0.13)^{* * *}\end{array}$ & $\begin{array}{l}0.07(0.03- \\
0.212)^{* * *}\end{array}$ & $\begin{array}{c}0.14(0.05- \\
0.40)^{* * *}\end{array}$ & $\begin{array}{l}1.64(0.78- \\
3.46 ; 0.20)\end{array}$ & $<0.001 * * *$ & $\begin{array}{l}0.03(0.01- \\
0.07)^{* * *}\end{array}$ & $\begin{array}{l}0.04(0.02- \\
0.13)^{* * *}\end{array}$ & $\begin{array}{c}0.08(0.03- \\
0.24)^{* * *}\end{array}$ & $\begin{array}{l}0.61(0.29- \\
1.30 ; 0.20)\end{array}$ & $<0.001^{* * *}$ \\
\hline
\end{tabular}

Note. An odds ratio (OR) or adjusted odds ratio (AOR) of 1 indicates the event is equally probable in each group, $>1$ indicates the event is more likely to occur in the non-

reference group relative to the reference group, and $<1$ indicates the event is less likely to occur in the non-reference group relative to the reference group.

${ }^{*} p<.050 ;{ }^{* *} p<.010 ;{ }^{* * *} p<.001$; exact $p$ values not presented where $<0.001$.

$\mathrm{Cl}$ : confidence interval; AOD: alcohol and/or drugs; AUDIT-C: Alcohol Use Disorders Identification Test; K10: Kessler Psychological Distress Scale; SES: socio-economic status. 


\section{References}

ANDREWS, G. \& SLADE, T. 2001. Interpreting scores on the Kessler Psychological Distress Scale (K10). Australian and New Zealand Journal of Public Health, 25, 494-497.

AUSTRALIAN BUREAU OF STATISTICS. 2013. Census of Population and Housing: SocioEconomic Indexes for Areas (SEIFA), Australia, 2011 [Online]. Available: http://www.abs.gov.au/Ausstats/abs@.nsf/0/4E5531D7B85288A9CA2577E4000E1F 9E?OpenDocument [Accessed 2 October 2017].

AUSTRALIAN INSTITUTE OF HEALTH \& WELFARE 2014. 2013 National Drug Strategy Household Survey: Detailed Findings. Drug statistics series no. 28. Cat. no. PHE 183. Canberra: Australian Institute of Health and Welfare.

AUSTRALIAN INSTITUTE OF HEALTH \& WELFARE 2017. National Drug Strategy Household Survey 2016. Detailed findings. Drug Statistics series no. 31. Cat. no. PHE 214.

BARRATT, M. J., SEEAR, K. \& LANCASTER, K. 2017. A critical examination of the definition of 'psychoactive effect' in Australian drug legislation. International Journal of Drug Policy, 40, 16-25.

BONAR, E. E., ASHRAFIOUN, L. \& ILGEN, M. A. 2014. Synthetic cannabinoid use among patients in residential substance use disorder treatment: Prevalence, motives, and correlates. Drug and Alcohol Dependence, 143, 268-271.

BRADLEY, K. A., DEBENEDETTI, A. F., VOLK, R. J., WILLIAMS, E. C., FRANK, D. \& KIVLAHAN, D. R. 2007. AUDIT-C as a Brief Screen for Alcohol Misuse in Primary Care. Alcoholism: Clinical and Experimental Research, 31, 1208-1217.

BRUNO, R., MATTHEWS, A. J., DUNN, M., ALATI, R., MCILWRAITH, F., HICKEY, S., BURNS, L. \& SINDICICH, N. 2012. Emerging psychoactive substance use among regular ecstasy users in Australia. Drug and Alcohol Dependence, 124, 19-25.

BRUNT, T. M., NAGY, C., BÜCHELI, A., MARTINS, D., UGARTE, M., BEDUWE, C. \& VENTURA VILAMALA, M. 2017. Drug testing in Europe: monitoring results of the Trans European Drug Information (TEDI) project. Drug Testing and Analysis, 9, 188-198.

BUSH, K., KIVLAHAN, D. R., MCDONELL, M. B., FIHN, S. D. \& BRADLEY, K. A. 1998. The AUDIT alcohol consumption questions (AUDIT-C): an effective brief screening test for problem drinking. Ambulatory Care Quality Improvement Project (ACQUIP). Alcohol Use Disorders Identification Test. Arch Intern Med, 158, 1789-95.

DARKE, S. 1998. Self-report among injecting drug users: A review. Drug \& Alcohol Dependence, 51, 253-263.

EMMANUEL, F. \& ATTARAD, A. 2006. Correlates of injection use of synthetic drugs among drug users in Pakistan: a case controlled study. J Pak Med Assoc, 56, 119-24.

EUROPEAN MONITORING CENTRE FOR DRUGS AND DRUG ADDICTION 2015. EMCDDA Eurpol 2014 Annual Report on the implementation of Council Decision 2005/387/JHA. Luxembourg: Publications Office of the European Union.

EUROPEAN MONITORING CENTRE FOR DRUGS AND DRUG ADDICTION 2016a. EMCDDA Eurpol 2015 Annual Report on the implementation of Council Decision 2005/387/JHA. Luxembourg: Publications Office of the European Union.

EUROPEAN MONITORING CENTRE FOR DRUGS AND DRUG ADDICTION 2016b. Health responses to new psychoactive substances. Luxembourg: Publications Office of the European Union. 
EUROPEAN MONITORING CENTRE FOR DRUGS AND DRUG ADDICTION 2016c. Health responses to new psychoactive substances. Luxembourg: Publications Office of the European Union.

EUROPEAN MONITORING CENTRE FOR DRUGS AND DRUG ADDICTION 2017a. EMCDDA Eurpol 2016 Annual Report on the implementation of Council Decision 2005/387/JHA. Luxembourg: Publications Office of the European Union.

EUROPEAN MONITORING CENTRE FOR DRUGS AND DRUG ADDICTION 2017b. High-risk drug use and new psychoactive substances. Results from an EMCDDA trendspotter study. . Luxembourg: Publications Office of the European Union.

HARRIS, A. H., BRADLEY, K. A., BOWE, T., HENDERSON, P. \& MOOS, R. 2010. Associations between AUDIT-C and mortality vary by age and sex. Popul Health Manag, 13, 263-8.

HASIN, D. S., O'BRIEN, C. P., AURIACOMBE, M., BORGES, G., BUCHOLZ, K., BUDNEY, A., COMPTON, W. M., CROWLEY, T., LING, W., PETRY, N. M., SCHUCKIT, M. \& GRANT, B. F. 2013. DSM-5 Criteria for Substance Use Disorders: Recommendations and Rationale. The American journal of psychiatry, 170, 834-851.

HOME OFFICE 2017. Drug Misuse: Findings from the 2016/17 Crime Survey for England and Wales. Statistical Bulletin 11/17. London: Home Office.

INTERGOVERNMENTAL COMMITTEE ON DRUGS 2014. Frame work for a National Response to New Psychoactive Substances. Canberra: Commonwealth of Australia.

JOSEPH, A. M., MANSEAU, M. W., LALANE, M., RAJPARIA, A. \& LEWIS, C. F. 2017.

Characteristics associated with synthetic cannabinoid use among patients treated in a public psychiatric emergency setting. American Journal of Drug and Alcohol Abuse, 43, 117-122.

KESSLER, R. C., BARKER, P. R., COLPE, L. J., EPSTEIN, J. F., GFROERER, J. C., HIRIPI, E., HOWES, M. J., NORMAND, S. L., MANDERSCHEID, R. W., WALTERS, E. E. \& ZASLAVSKY, A. M. 2003. Screening for serious mental illness in the general population. Arch Gen Psychiatry, 60, 184-9.

LAWN, W., BARRATT, M., WILLIAMS, M., HORNE, A. \& WINSTOCK, A. 2014. The NBOMe hallucinogenic drug series: Patterns of use, characteristics of users and self-reported effects in a large international sample. Journal of Psychopharmacology, 28, 780-788.

LO, Y., MENDELL, N. R. \& RUBIN, D. B. 2001. Testing the number of components in a normal mixture. Biometrika, 88, 767-778.

MANSEAU, M. W., RAJPARIA, A., JOSEPH, A., AZARCHI, S., GOFF, D., SATODIYA, R. \& LEWIS, C. F. 2017. Clinical Characteristics of Synthetic Cannabinoid Use in a Large Urban Psychiatric Emergency Setting. Substance Use and Misuse, 52, 822-825.

MOORE, K., DARGAN, P. I., WOOD, D. M. \& MEASHAM, F. 2013. Do Novel Psychoactive Substances Displace Established Club Drugs, Supplement Them or Act as Drugs of Initiation? The relationship between Mephedrone, Ecstasy and Cocaine. European Addiction Research, 19, 276-282.

MUTHÉN, L. K. \& MUTHÉN, B. O. 2010. Mplus User's Guide. Sixth Edition., Los Angeles, CA, Muthén \& Muthén.

PALAMAR, J. J. 2015. "Bath salt" use among a nationally representative sample of high school seniors in the United States. The American Journal on Addictions, 24, 488-491.

PALAMAR, J. J. \& ACOSTA, P. 2015. Synthetic cannabinoid use in a nationally representative sample of US high school seniors. Drug and Alcohol Dependence, 149, 194-202. 
PALAMAR, J. J., ACOSTA, P., CALDERON, F. F., SHERMAN, S. \& CLELAND, C. M. 2017. Assessing self-reported use of new psychoactive substances: The impact of gate questions. Am J Drug Alcohol Abuse, 43, 609-617.

PALAMAR, J. J., MARTINS, S. S., SU, M. K. \& OMPAD, D. C. 2015. Self-Reported Use of Novel Psychoactive Substances in a US Nationally Representative Survey: Prevalence, Correlates, and a Call for New Survey Methods to Prevent Underreporting(). Drug and alcohol dependence, 156, 112-119.

RÁCZ, J., CSÁK, R., TÓTH, K. T., TÓTH, E., ROZMÁN, K. \& GYARMATHY, V. A. 2016. Veni, vidi, vici: The appearance and dominance of new psychoactive substances among new participants at the largest needle exchange program in Hungary between 2006 and 2014. Drug and Alcohol Dependence, 158, 154-158.

RALPHS, R., WILLIAMS, L., ASKEW, R. \& NORTON, A. 2017. Adding Spice to the Porridge11'Porridge' is British slang for a prison sentence. E.g. 'Doing his porridge'. The term is most commonly thought to be an allusion to the fact that porridge is, or used to be, a common food in prison. The term is also thought to be a pun on the much older slang word for prison, 'stir'.: The development of a synthetic cannabinoid market in an English prison. International Journal of Drug Policy, 40, 57-69.

RAMO, D. E., GROV, C., DELUCCHI, L., KELLY, B. C. \& PARSONS, J. T. 2010. Typology of club drug use among young adults recruited using time-space sampling. Drug and Alcohol Dependence, 107, 119-127.

ROY MORGAN RESEARCH 2014. National Drug Strategy Household Survey 2013. Final Technical Report. Melbourne: Roy Morgan Research.

SALOMONE, A., PALAMAR, J. J., GERACE, E., DI CORCIA, D. \& VINCENTI, M. 2017. Hair Testing for Drugs of Abuse and New Psychoactive Substances in a High-Risk Population. $J$ Anal Toxicol, 41, 376-381.

SUTHERLAND, R., PEACOCK, A., WHITTAKER, E., ROXBURGH, A., LENTON, S., MATTHEWS, A., BUTLER, K., NELSON, M., BURNS, L. \& BRUNO, R. 2016. New psychoactive substance use among regular psychostimulant users in Australia, 2010-2015. Drug and Alcohol Dependence, 161, 110-118.

TARJÁN, A., DUDÁS, M., WIESSING, L., HORVÁTH, G., RUSVAI, E., TRESÓ, B. \& CSOHÁN, Á. 2017. HCV prevalence and risk behaviours among injectors of new psychoactive substances in a risk environment in Hungary-An expanding public health burden. International Journal of Drug Policy, 41, 1-7.

THAI, P. K., LAI, F. Y., EDIRISINGHE, M., HALL, W., BRUNO, R., O'BRIEN, J. W., PRICHARD, J., KIRKBRIDE, K. P. \& MUELLER, J. F. 2016. Monitoring temporal changes in use of two cathinones in a large urban catchment in Queensland, Australia. Science of The Total Environment, 545, 250-255.

THE DRUGS WHEEL. A NEW MODEL FOR SUBSTANCE AWARENESS. 2018. Available: http://www.thedrugswheel.com/?page=home [Accessed 7 March 2018].

VREEKER, A., VAN DER BURG, B. G., VAN LAAR, M. \& BRUNT, T. M. 2017. Characterizing users of new psychoactive substances using psychometric scales for risk-related behavior. Addictive Behaviors, 70, 72-78. 